Marlowe, and partly of his age. It might have been treated quite in conformity with the general belief; it might have been a tale of sorcery, and yet magnificently impressive. What would not Shakespeare have made of it? Nevertheless, we must in justice to Marlowe look also to the state of opinion in his time; and we shall then admit that another and higher mode of treatment would perhaps have been less acceptable to the audience. Had it been metaphysical, they would not have understood it; had the motives of Faustus been more elevated, the audience would not have believed in them. To have saved him at last, would have been to violate the legend, and to outrage their moral sense. For, why should the black arts be unpunished? why should not the sorcerer be damned? The legend was understood in its literal sense, in perfect accordance with the credulity of the audience. The symbolical significance of the legend is entirely a modern creation.

(from The Life and Works of Goethe (1855) pp. 469, 471)

\title{
H. A. TAINE
}

[MARLOWE's Faustus is] the living, struggling, natural, personal man, not the philosophic type which Goethe has created, but a primitive and genuine man, hot-headed, fiery, the slave of his passions, the sport of his dreams, wholly engrossed in the present, molded by his lusts, contradictions, and follies, who amidst noise and starts, cries of pleasure and anguish, rolls, knowing it and willing it, down the slope and crags of his precipice.

(from History of English Literature (1863-4; trans. H. van Laun, 187I) bk II, ch. II iv)

\section{A. W. WARD}

[THE] moral of the tragedy ... is simple enough, - 'unlawful things' are to be wondered at but not to be practised; yet it had its meaning for Marlowe's age, and for Marlowe's mind. His age 